7. Reprod. Fert. (1969) 18, 107-113

\title{
THE RELATIONSHIP BETWEEN DAY OF FORMATION AND FUNCTIONAL LIFE SPAN OF INDUCED CORPORA LUTEA IN THE PIG
}

\author{
B. V. GALDWELL, R. M. MOOR, I. WILMUT, G. POLGE \\ AND L. E. A. ROWSON \\ A.R.C. Unit of Reproductive Physiology and Biochemistry, University of Cambridge
}

(Received 25th April 1968)

\begin{abstract}
Summary. Corpora lutea induced in pigs on Day 6 regressed with the naturally formed corpora lutea towards the end of the cycle. Hormonal induction of corpora lutea on Days 8,10 or 16 significantly prolonged the cycle despite involution of the original corpora lutea about 16 days after ovulation. The interval between the exogenous administration of HCG and the appearance of the next oestrus varied with the day on which the accessory corpora lutea were formed. The estimated functional life span of the corpora lutea induced on Days $6,8,10$ and 16 was 12.5, 14.5, 15.0 and 19.3 days respectively. That these induced corpora lutea were fully functional was shown by the luteal progesterone levels estimated using the protein-binding and u.v. spectrophotometric techniques.

Hysterectomy resulted in both the spontaneous corpora lutea and those induced on Day 6 being maintained for at least 60 days.

It is concluded that Days 6 to 8 may represent a critical phase in the relationship between the uterus and the corpora lutea in non-pregnant pigs.
\end{abstract}

\section{INTRODUGTION}

The mechanisms which regulate the functional life span of corpora lutea remain largely unknown. However, the administration of hormones to induce an experimental set of corpora lutea which differ in age and developmental stage from the natural set may provide some insight into the factors which influence the luteal life span.

In swine, corpora lutea induced between the 9th and 15th day after oestrus did not regress with the original luteal tissue but remained functional and extended the oestrous cycle (Neill \& Day, 1964). These authors suggested that the two sets of corpora lutea had approximately the same functional life span regardless of the day on which new ovulations were induced.

In sheep, however, corpora lutea induced on Day 5, 9 or 13 regressed at the same time as the natural luteal tissue without causing a significant extension of the oestrous cycle (Inskeep, Oloufa, Pope \& Casida, 1963). 
These results suggest that, in the pig, induced corpora lutea have a predetermined life span independent of the factors which operate to cause the regression of the previously formed, natural luteal tissue. This is in contradistinction to the sheep where the factors regulating luteal life span appear to cause synchronous involution of both natural and induced corpora lutea regardless of the difference in their developmental stage.

The present investigation was designed to study further the possibility that porcine corpora lutea may have a predetermined life span and to define the time at which the mechanisms for causing luteal regression are operating.

Progesterone analyses were carried out to compare the functional capabilities of both natural and induced corpora lutea at critical times during the oestrous cycle. The protein-binding method (Murphy, 1967) was adapted for determining progesterone concentrations in luteal tissue and a direct comparison was made with the u.v. spectrophotometric assay (Rowlands \& Short, 1959).

\section{MATERIALS AND METHODS}

Pure or cross-bred Large White gilts, weighing 200 to $300 \mathrm{lb}$, were checked daily with a boar for oestrous behaviour and the first day of heat was designated Day 0. Following one or more normal cycles (i.e. 19 to 23 days), new ovulations were induced on Days $6,8,10$ or 16 by the subcutaneous injection of 750 i.u. pregnant mare's serum gonadotrophin (Freeze Dried, Burroughs Wellcome), followed $72 \mathrm{hr}$ later (Days 4, 6, 8 or 14) by 2000 i.u. of human chorionic gonadotrophin ('Lutormone', Burroughs Wellcome) administered by intravenous injection.

A total of fifty gilts was used, divided into the following four groups at random: those in which ovulations were to be induced (1) on Day 6 (twenty), (2) on Day 8 (seven), (3) on Day 10 (thirteen), (4) on Day 16 (ten). The length of the oestrous cycle immediately preceding treatment for all pigs was measured and forms the control group in Table 3.

Laparotomies were performed 3 to 4 days after HCG administration and the induced set of corpora lutea was marked for future identification with sterile animal charcoal. Two animals from Group 1 were hysterectomized following the marking of the corpora lutea on Day 8 and observed for signs of oestrus for 60 days. The ovaries were excised at autopsy and the luteal tissue examined histologically. Six animals from Group 1 and two from Group 3 were killed on selected days of the oestrous cycle. Representative corpora lutea from the spontaneous and induced set were fixed in Bouin's fluid for histological studies or frozen immediately for progesterone analysis. The remaining animals in each group were killed on the day following the first post-operative oestrus and accurate counts were made of all corpora albicantia present.

Progesterone determinations were carried out by the protein-binding method (Murphy, 1967; Neill, Johansson, Datta \& Knobil, 1967) while selected corpora lutea were simultaneously analysed according to the method of Rowlands \& Short (1959) for comparison with previously reported values (Masuda, Anderson, Henricks \& Melampy, 1967; Day, 1964).

For the protein-binding assays, from 500 to $750 \mathrm{mg}$ of luteal tissue was 
homogenized in $5 \mathrm{ml}$ of $10 \% \mathrm{NaOH}$ and extracted with $50 \mathrm{ml}$ petroleum ether (40-60). The $\mathrm{NaOH}$ phase was re-homogenized with an additional $5 \mathrm{ml} 10 \%$ $\mathrm{NaOH}$ and extracted again in $50 \mathrm{ml}$ petroleum ether. The pooled extract was washed four times with $8 \mathrm{ml}$ distilled water and aliquots of $0.2,0.4$ and $1.0 \mathrm{ml}$ were dried under nitrogen for analysis. No thin layer separation of the petroleum ether aliquots was required as Booth \& Schomberg (1968) have shown that at least $95 \%$ of the progestins present in porcine luteal tissue is progesterone. Recoveries were estimated by the addition of labelled progesterone to duplicate samples and values corrected for each determination.

\section{RESULTS}

\section{Induction of experimental corpora lutea}

Both the success rate for inducing supernumerary corpora lutea and the average number of ovulations varied considerably among the four groups (Table 1). In animals treated early (Day 4) or late (Day 14) with HGG, the success rate and average ovulation number were lower than in pigs treated during mid-cycle.

TABLE 1

INDUGTION OF GORPORA LUTEA DURING THE PORGINE OESTROUS GYGLE

\begin{tabular}{c|c|c|c|c|c|c}
\hline Group & $\begin{array}{c}\text { Day of } \\
\text { HCG }\end{array}$ & $\begin{array}{c}\text { Day of } \\
\text { ovulation }\end{array}$ & $\begin{array}{c}\text { Number } \\
\text { treated }\end{array}$ & $\begin{array}{c}\text { Animals } \\
\text { ovulated }\end{array}$ & $\%$ success & $\begin{array}{c}\text { Average no. } \\
\text { ovulations }\end{array}$ \\
\cline { 2 - 4 } & 4 & 6 & 20 & 14 & 70 & $8 \cdot 2$ \\
2 & 6 & 8 & 7 & 7 & 100 & $10 \cdot 9$ \\
3 & 8 & 10 & 13 & 9 & 89 & $10 \cdot 0$ \\
4 & 14 & 16 & 10 & 7 & 70 & $6 \cdot 9$ \\
\hline
\end{tabular}

\section{Functional capabilities of the corpora lutea}

Progesterone concentrations as determined by the protein-binding method agreed well with those reported earlier (Masuda et al., 1967; Day, 1964) and with figures obtained simultaneously by the u.v. spectrophotometric assay (Table 2).

On Day 12 of the oestrous cycle, the levels of progesterone in the spontaneous corpora lutea were higher than those found in the induced luteal tissue, perhaps reflecting the 4-day difference in age (Group 1, Table 2). By Day 18, in animals with corpora lutea induced on Day 6 , both sets of luteal tissue showed a decrease in progesterone concentration and the spontaneous corpora lutea appeared to have regressed slightly in advance of those induced. On Day 19, progesterone concentrations were lower still and histological evidence confirmed that regression was nearly complete in all corpora lutea studied (Group 1, Table 2).

On Day 23, in two animals with corpora lutea induced on Day 10, the level of progesterone in this tissue was very high while the original corpora lutea had become corpora albicantia with very low hormone concentrations (Group 3, Table 2). 


\section{Cycle length as influenced by the induced corpora lutea}

The length of the oestrous cycle was significantly longer than normal in animals with corpora lutea induced on Days 8, 10 or 16 (Groups 2, 3 and 4, Table 3), whereas corpora lutea induced on Day 6 had no effect on cycle length (Group 1, Table 3). There was also a significant difference between the

TABLE 2

CONCENTRATION OF PROGESTERONE IN SPONTANEOUS AND INDUCED CORPORA LUTEA ON SELEGTED DAYS OF THE OESTROUS GYGLE

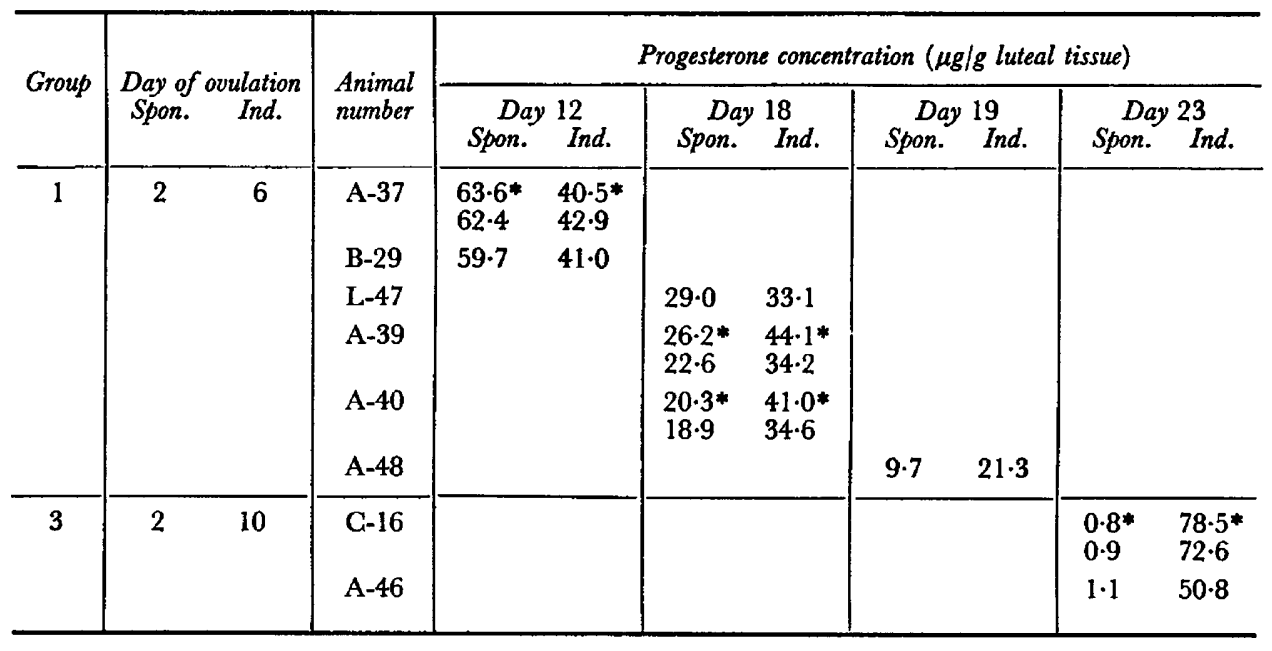

* Determined by u.v. spectrophotometric method.

TABLE 3

LENGTH OF OESTROUS CYCLE AS INFLUENGED BY INDUGED GORPORA LUTEA

\begin{tabular}{c|cc|c|c}
\hline Group & $\begin{array}{c}\text { Day of ovulation } \\
\text { Spon. } \\
\text { Ind. }\end{array}$ & $\begin{array}{c}\text { Mean cycle* } \\
\text { length (days) }\end{array}$ & $\begin{array}{c}\text { Interval between } \\
\text { HCG and } \\
\text { oestrus (days) }\end{array}$ \\
\hline Control $\dagger$ & 2 & - & $21 \cdot 0 \pm 0.17$ & - \\
1 & 2 & 6 & $21.5 \pm \pm 0.22$ & 17.5 \\
2 & 2 & 8 & $25.5 \pm 0.92$ & 19.5 \\
3 & 2 & 10 & $28.0 \pm 0.30$ & 20.0 \\
4 & 2 & 16 & $38 \cdot 3 \pm 1 \cdot 10$ & $24 \cdot 3$ \\
\hline
\end{tabular}

* Mean \pm standard error.

$\uparrow$ The length of the oestrous cycle immediately preceding treatment of all animals used in Groups 1 to 4.

cycle length of animals with corpora lutea induced on Days 8 or 10 as compared with animals with corpora lutea induced on Day 16 (Groups 2, 3 and 4, Table 3).

A comparison of the intervals between exogenous administration of HCG and the appearance of the next oestrus clearly shows that the effects of inducing corpora lutea vary significantly in relation to the day on which the accessory 
corpora lutea were formed. HCG administration on Day 4 and corpora lutea formation on Day 6 resulted in an LH to oestrus interval of only 17.5 days (Group 1, Table 3). This interval was significantly extended when HCG was given on Days 6, 8 or 14 (Groups 2, 3 and 4, Table 3). As can be seen, there was no difference between the animals with corpora lutea formed on Days 8 or 10, but both differed significantly from the group of animals which ovulated on Day 16 (Table 3).

\section{Effect of hysterectomy}

Two animals with corpora lutea induced on Day 6 and hysterectomized on Day 8 did not return to heat for 60 days. A histological examination of the ovaries clearly showed both sets of luteal tissue to be similar to normal corpora lutea at mid-cycle.

\section{DISGUSSION}

Any attempt to assign significance to the findings of this investigation must be based on the assumption that hormonally induced corpora lutea are physiologically normal. This assumption would seem justified, however, since the experimental luteal tissue produces normal levels of progesterone, maintains the oestrous cycle in the absence of active spontaneous corpora lutea, and is histologically indistinguishable from naturally formed luteal tissue.

An estimation of the functional life span of the spontaneous and experimentally induced corpora lutea is based on the time of their formation and regression in relation to the length of the oestrous cycle. Ovulation normally occurs about 36 to $55 \mathrm{hr}$ after the onset of oestrus (Burger, 1952; Thibault, 1959) and spontaneous corpora lutea are therefore formed on Day 2 of the cycle. The spontaneous corpora lutea regress about 3 days before the appearance of the next oestrus (Masuda et al., 1967) and thus have a functional life span of about 16 days. Ovulation induced by exogenous gonadotrophins occurs 40 to $42 \mathrm{hr}$ after the injection of HCG (Dziuk, Polge \& Rowson, 1964; Hunter, 1967). The laparotomies which were performed in these experiments 3 days after the injection of HGG confirmed that ovulation had occurred at the expected time and from the histological observations it would appear that the induced corpora lutea also regressed about 3 days before the appearance of oestrus. An extrapolation of the HGG to oestrus interval (Table 3), therefore, gives an estimated life span for the corpora lutea induced on Days 6, 8, 10 and 16 of 12.5, 14.5, 15.0 and $19 \cdot 3$ days, respectively.

Using the same technique, Neill \& Day (1964) advanced the possibility that porcine corpora lutea may have a predetermined life span since corpora lutea induced during mid-cycle (Days 9 to 14) did not regress with the original luteal tissue but caused an extension of the oestrous cycle and had a life span approaching normal. The results of the present investigation cannot support this view entirely, for while confirming that corpora lutea induced during mid-cycle (Days 8 and 10) do not regress with the original luteal tissue it was found that the induction of new corpora lutea on Day 6 resulted in a normal cycle length and therefore a much reduced life span for the induced luteal tissue (Table 3). Also, 
the induction of new corpora lutea late in the cycle, on Day 16, extended the functional life span of the experimental luteal tissue to an estimated mean of $19 \cdot 3$ days, 3 days longer than normal. The authors concluded from this evidence that porcine corpora lutea do not have a predetermined life span and that the factors operating to influence the demise of the natural corpora lutea have an effect on the induced tissue. The extent of this luteolytic effect would seem to be a function of the day of formation of the induced corpora lutea.

The striking difference between corpora lutea induced on Day 6, which regress slightly after the spontaneous tissue at the normal time, and those induced on Day 8 , which continue to function after the demise of the natural tissue on Day 18, suggests that Days 6 to 8 may mark the stage at which the factors which operate to determine the life span of porcine corpora lutea have their initial effect. Support for this view can be found in the work of Cavazos (personal communication) who found the first signs of regression in electron micrographs of Day-8 porcine corpora lutea. He noted that at Day 8 of the cycle, a few residual bodies (lysosomes) were present. The formation of these residual bodies continued and, by Day 12 of the cycle, there was considerable lysosomal activity.

It is well established that hysterectomy in the pig interrupts the normal ovarian periodicity and corpora lutea are maintained for a period slightly longer than gestation (Du Mesnil du Buisson \& Dauzier, 1959). Neill \& Day (1964) reported that hysterectomy maintained the spontaneous corpora lutea and those induced on Days 9,10 or 11 , while the present study extends this observation to luteal tissue induced on Day 6. The presence of the uterus is required, then, from at least Day 8 in order for luteal regression to proceed at the normal time. Du Mesnil du Buisson (1966) reported that hysterectomy as late in the cycle as Day 16 could block the final stages of luteal regression, while removing the uterus any later than this usually resulted in involution of the corpora lutea. The influence of the uterus may, therefore, be a continuous one acting over a duration of 8 to 10 days.

The sheep presents an interesting contrast to the pig since in the ewe the process of luteal regression appears to be very rapid, taking place in about 24 hours (Deane, Hay, Moor, Rowson \& Short, 1966). The results of Inskeep et al. (1963) confirm this rapid involution as corpora lutea induced on Days 5, 9 or 13 all regressed with the normal luteal tissue on Day 15. If the process of luteal regression in the pig is 8 to 10 days, as suggested by the present investigation, then a comparison with the 1-day breakdown of corpora lutea in the sheep may explain the difference in results obtained when inducing new corpora lutea in the two species.

In conclusion, the results of this investigation suggest that porcine corpora lutea do not have a predetermined life span and that the period between Day 6 and Day 8 may be critical in establishing the factors which influence the regression of corpora lutea.

\section{ACKNOWLEDGMENTS}

The authors wish to acknowledge with appreciation the assistance of $\mathrm{Mr}$ 
Derek Booth and Mr Hugh Strange. B.V.C. was supported by a National Science Foundation grant and I.W. by a P.I.D.A. post-graduate scholarship.

\section{REFERENGES}

Boоth, W. D. \& Schomberg, D. W. (1968) The isolation of 20a- and 20 $\beta$-hydroxypregn-4-en-3-one from porcine corpora lutea. F. Endocr. 42, 603.

Burger, J. F. (1952) Sex physiology of pigs. Onderstepoort 7. vet. Res., Suppl. No. 2.

DAY, B. N. (1964) The life span of corpora lutea induced during the luteal phase of the estrus cycle in swine. Conf. on estrus cycle control in domestic animals. University of Nebraska. U.S. Dept. Agriculture. Misc. Publs, 1005, 78.

Deane, H. W., Hay, M. F., Moor, R. M., Rowson, L. E. A. \& Short, R. V. (1966) The corpus luteum of the sheep: relationships between morphology and function during the oestrous cycle. Acta endocr., Copenh. 51, 245.

Du Buisson, F. Du Mesnil (1966) Contribution à l'étude du maintien du corps jaune de la truie. Thesis, Paris.

Du Buisson, F. Du Mesnit \& Dauzier, L. (1959) Controle mutuel de l'uterus et de l'ovaire chez la truie. Ann. Zootechnie, Series D, Suppl. 147.

Dzuik, P. J., Polge, G. \& Rowson, L. E. A. (1964) Intra-uterine migration and mixing of embryos in swine following egg transfer. F. Anim. Sci. 23, 37.

Hunter, R. H. F. (1967) Porcine ovulation after injection of human chorionic gonadotrophin. Vet. Rec. $81,21$.

Inskeep, E. D., Oloufa, M. M., Pope, A. L. \& Casida, L. E. (1963) Functional capabilities of experimentally induced corpora lutea in ewes. F. Anim. Sci. 22, 159.

Masuda, H., Anderson, L. L., Henricks, D. M. \& Melampy, R. M. (1967) Progesterone in ovarian venous plasma and corpora lutea of the pig. Endocrinology, 80, 240.

Murphy, B. E. P. (1967) Some studies of the protein-binding of steroids and their application to the routine micro and ultra micro measurement of various steroids in body fluids by competitive protein-binding radioassay. F. clin. Endocr. 27, 973.

NeILL, J. D. \& DAY, B. N. (1964) Relationship of developmental stage to regression of the corpus luteum in swine. Endocrinology, 74, 355.

Neill, J. D., Johansson, E. D. B., Datta, J. K. \& Knobil, E. (1967) Relationship between plasma levels of luteinizing hormone and progesterone during the normal menstrual cycle. $\mathcal{F}$. clin. Endocr. 27, 1167.

Rowlands, I. W. \& Shorr, R. V. (1959) The progesterone content of the guinea-pig corpus luteum during the reproductive cycle and after hysterectomy. F. Endocr. 19, 81 .

Thibault, G. (1959) Analyse de la fécondation de l’œuf de la truie après accouplement ou insémination artificielle. Ann. Zootechnie, Series D, Suppl. 165. 